\title{
Quantification and distribution of 4-fluoroisobutyryl fentanyl (4-FiBF) in postmortem biological samples using UHPLC-QqQ-MS/MS
}

\author{
Marcin Zawadzki ${ }^{1,2}$ (D) Olga Wachełko ${ }^{2} \cdot$ Agnieszka Chłopaś-Konowałek $^{2} \cdot$ Paweł Szpot $^{1,2}$
}

Received: 24 March 2021 / Accepted: 10 May 2021 / Published online: 24 May 2021

(c) The Author(s) 2021

\begin{abstract}
Purpose Development of ultra-high-performance liquid chromatography-triple quadrupole tandem mass spectrometry method for quantification of 4-fluoroisobutyryl fentanyl (4-FiBF) and its distribution in postmortem biological samples in four fatal intoxication cases, which occurred in September 2018, in Poland.

Methods Biological fluids (blood, urine, vitreous humor, bile, gastric content) and tissues (brain, kidney, liver, stomach wall) were extracted with ethyl acetate from alkaline medium ( $\mathrm{pH} 9$ ). Fentanyl- $d_{5}$ was used as internal standard.

Results The validation parameters were as follows: lower limit of quantification: $0.1 \mathrm{ng} / \mathrm{mL}$ (biological fluids) and $0.1 \mathrm{ng} / \mathrm{g}$ (solid tissues), intra- and inter-day accuracies and precisions: not greater than 20\%; recovery values: $86.9-110 \%$; matrix effect: $-13.1-10.4 \%$. Among all tested biological fluid, the highest concentration of 4-FiBF was found in bile (average concentration of $3390 \mathrm{ng} / \mathrm{mL}$ ) while among the tissues, in liver (average concentration of $1650 \mathrm{ng} / \mathrm{g}$ ). Furthermore, in collected specimens, there were also found other drugs and new psychoactive substances (NPS) e.g. $N$-ethylpentylon, 4-chloromethcathinone (4-CMC) and $\alpha$-pyrrolidinoisohexanophenone ( $\alpha$-PiHP). Concentrations and distributions of these substances in postmortem samples have been also detailed. Examinations of seized drug (in case 4) revealed that it included the mix of 4 -FiBF and $\alpha$-PiHP.

Conclusions The developed and fully validated method enabled for determination of 4-FiBF in postmortem biological fluids and tissues. To our knowledge, this is the first report of distribution study of 4-FiBF with other NPS ( $N$-ethylpentylon, $4-\mathrm{CMC}$ and $\alpha$-PiHP) in authentic fatal intoxication cases.
\end{abstract}

Keywords New psychoactive substance $\cdot$ 4-Fluoroisobutyryl fentanyl $\cdot$ 4-FiBF $\cdot$ Fatal intoxication $\cdot$ Postmortem distribution · UHPLC-QqQ-MS/MS

\section{Introduction}

Synthetic opioids pose a high risk of intoxication to consumers and are an example of progressive drug market adaptability. International legal regulations related to the illicit distribution of drugs have resulted in increasing structural modifications to new psychoactive substances (NPS) released onto the global drug market. Since 2009, there have been 57 new synthetic opioids introduced to Europe's

Marcin Zawadzki

marcin.zawadzki@umed.wroc.pl

1 Department of Forensic Medicine, Wroclaw Medical University, 4 J. Mikulicza-Radeckiego Street, 50345 Wroclaw, Poland

2 Institute of Toxicology Research, 45 Kasztanowa Street, 55093 Borowa, Poland drug market. According to the latest European Monitoring Centre for Drugs and Drug Addiction (EMCDDA) report [1], in 2019, 8 new opioids were seized for the first time, including two totally novel fentanyl analogs. The opioid crisis can also be observed in North America. The present and most deadly wave of fentanyl analog use began in the United States around 2013. Similarly, in Canada, the levels of opioid-related deaths has increased since 2016. Between January and December 2019 alone, there were 77\% intoxications involving fentanyl or fentanyl analogs, while seizures of fentanyl increased from about $96 \mathrm{~kg}$ in 2015 to more than 2.9 tons in 2018 [2]. Like in North America and Europe, East and Southeast Asia is also observing a large amount of fentanyl analogs reported annually. Japan reported the largest number of NPS, followed by China and Singapore [3]. According to an United Nations Office on Drugs and Crime (UNODC) report (October 2020), the opioid crisis is 
a global complex problem, whose nature seems to be a combination of factors, including lowering costs by organized crime groups through substitution of pharmaceutical opioids with fentanyl analogs and other synthetic opioids [2].

4-Fluoroisobutyryl fentanyl (4-FiBF) is one of the fentanyl analogs, which differs from the original drug by the presence of a fluorine atom and isobutyramide in place of the propenamide group. The first official EMCDDA-Europol notification of 4-FiBF was on August 26, 2016 from the Slovenian National Forensic Laboratory. White powder (5 g) was collected as test purchased and shipped from China as a part of the EU co-funded project RESPONSE [4]. As a seizure, 4-FiBF was first identified in November 2016 by German Police in Berlin. From 2016 to 2017 in total, there were 22 other seized drugs reported in Sweden (20), Belgium (1) and the United Kingdom (1) [5]. Due to the varied manufactured formulas in which 4-FiBF can be found (powders, tablets, liquids, blotters and herbal smoking mixtures), there are different ways to take this drug. It can be administered orally, rectally, intranasally via a spray, inhaled by smoking or injected intravenously and intramuscularly. For this reason, 4-FiBF distribution and its concentrations in different tissues and biological fluids can vary significantly [6]. In Europe, one of the first fatal intoxications which was associated with 4-FiBF occurred in September 2016 and was reported by the Swedish STRIDA project. Postmortem serum concentration of 4-FiBF after intravenous injection was $38 \mathrm{ng} / \mathrm{mL}$ [7], however, it is worth noting that the patient was reanimated with naloxone before his death. Twenty-six deaths in the US in which 4-FiBF was detected as one of the fentanyl analogs were also reported during a similar time period [8].

Progressively, this analog became increasingly popular on the drug market, especially due to its easy availability for purchase on the Internet. The eDarkTrends project developed by Lamy et al. [9] revealed that between 2018 and 2019, 4-FiBF was third the most commonly advertised fentanyl analog among darknet customers. Forensic testing of illicit drug seizures in Hong Kong also confirmed this trend. In the years 2016-2018, 4-FiBF along with cyclopropylfentanyl were the mostly detected fentanyl-related substances [10].

A large toxicological study performed by Pardi et al. [11] based on evaluation of 4-FiBF in blood samples from 247 authentic cases in New York City occurring between 2017 and 2018, revealed that postmortem concentration levels of these drug can reach the value even of $331 \mathrm{ng} / \mathrm{mL}$. Compared to the fentanyl, 4-FiBF concentrations are an order of magnitude higher. In part, it can be explained by binding and functional activity data of opioid receptors in the context of fentanyl and its analogs. The half-maximal effective concentration, EC50 (nM), value represents the concentration that causes a half-maximal response of the receptor agonist.
In vitro studies of pharmacodynamics shows that for fentanyl these values are around 28.8, 996 and $347 \mathrm{nM}$ for $\mu$-, $\delta$ - and $\kappa$ - opioid receptors, respectively. In contrast, the values of EC50 for 4-FiBF in context of $\mu$-, $\delta$ - and $\kappa$ - opioid receptors are 115,2490 and $1330 \mathrm{nM}$, respectively. Accordingly, the study indicates that more 4-FiBF is needed to achieve half of the maximum receptor response compared to fentanyl. Similar impressions are shared by participants in online forums, who noted that 4-FiBF is long lasting and less euphorigenic when compared to other opioids [6]. This fact might lead users to increase the doses and may be the reason for such high concentrations of this drug in postmortem samples.

Drug detection in health care centers in acute poisoning cases is often performed using commercial immunochemical assays. However, a major limitation is their cross-reactivity. Wharton et al. [12] performed an extended study of the reactivity of fentanyl analogs using immunoassay kits. The investigations showed that analogs with $N$-aryl substitutions (such as 4-FiBF) are relatively poorly detectable by immunochemical methods. Despite its high structural similarity to the fentanyl, $p$-fluoro substituent on the phenyl ring with a methyl group in the acyl fragment of the anilide is not well tolerated in commercially available kits. Furthermore, these NPS exhibited average cross-reactivities of $10-30 \%$ across all fentanyl-targeting kits and almost $50 \%$ across individual kit types. For this reason, to date, the most sensitive, selective and reliable methods for the determination of fentanyl analogs in biological samples are those based on chromatographic separation with mass spectrometry detection.

The determination of 4-FiBF in biological samples was performed using chromatographic methods: high-performance liquid chromatography coupled with triple quadrupole tandem mass spectrometry (HPLC-QqQ-MS/MS) in blood samples [11, 13, 14]; ultra-high-performance liquid chromatography coupled with ion trap and tandem mass spectrometry (UHPLC-Ion Trap-MS ${ }^{\mathrm{n}}$ ) in blood, urine and tissues samples [8]; UHPLC coupled with tandem mass spectrometry and triple quadrupole linear ion trap (UHPLC-QTRAP-MS/MS) in blood [15] and hair samples [16]. In turn, the determination of 4-FiBF in seized drugs was performed through the use of gas chromatographic methods: coupled with tandem cold electron ionization mass spectrometry (GC-cold EI-MS/MS) and with vacuum ultraviolet detection (GC-VUV) [17] as well as gas chromatography with infrared detector (GC-IRD) [18].

\section{Case history and pathological findings}

The bodies of a 33-year-old male (case 1) and a 38-year-old male (case 2) were discovered in an apartment. No detailed information regarding the circumstances of the incident was available. Internal and external examinations of the corpses 
showed edema of the brain tissue, pulmonary emphysema as well as acute gastritis in both the deceased.

An ambulance was called for an unconscious 38-yearold male (case 3). The physician diagnosed sudden cardiac arrest. After transport to the hospital, the man was still unconscious and unresponsive to impulses. Resuscitation was carried out unsuccessfully, and finally, the man's death was confirmed. The autopsy did not reveal any pathological lesions.

A 22-year-old female (case 4) was found in an apartment. According to witnesses' statements, 2 days before her death the woman had been using recreational drugs. The next day, she complained about feeling unwell. Furthermore, the woman had been taking analgesics after an accident and lower limb injury. A plastic bag containing a white powder was found in the woman's apartment. The total weight of seized powder was $57.8 \mathrm{mg}$. External and internal examination of the corpse revealed cerebral tissue edema, pulmonary emphysema, and acute mucositis.

In each case, the participation of third parties in the deaths were excluded. For further toxicological analysis, biological fluids and tissues were collected. In cases 1 and 2: blood, urine, vitreous humor, bile, brain, kidney, liver and gastric content; in case 3: blood, vitreous humor, bile, brain, kidney, liver and stomach wall; in case 4: blood, urine, vitreous humor, brain, liver and gastric content. All the blood samples were collected in tubes containing sodium fluoride as the preservative agent. Toxicological investigations found 4-FiBF in all collected postmortem materials along with other drugs and NPS. Analysis for low molecular volatile compounds did not reveal the presence of ethanol and its congeners (methanol, acetone, and isopropanol) in any of the reported cases.

This paper aims to apply an UHPLC-QqQ-MS/MS method for quantification of 4-FiBF and its distribution in authentic postmortem biological fluids (blood, urine, bile, vitreous humor, gastric content) and tissues (brain, liver, kidney, stomach wall) in four fatal intoxications which occurred in September 2018 in Poland.

\section{Materials and methods}

\section{Chemicals}

Water (Chromasolv® LC-MS), methanol (Chromasolv® LC-MS), ethyl acetate, formic acid and fentnyl- $d_{5}$ were purchased from Sigma-Aldrich (Steinheim, Germany); ammonium formate from Sigma-Aldrich (Bangalore, India); ammonium carbonate from Fluka (Buchs, Switzerland); 4-fluoroisobutyryl fentanyl (4-FiBF) from Chiron (Trondheim, Norway). Standard solutions of 4-FiBF and internal standard (IS) fentanyl- $d_{5}$, at concentration of $100 \mu \mathrm{g} / \mathrm{mL}$ were prepared in methanol.

\section{Biological material}

Drug-free blank blood samples used for the development and validation of the method were obtained from Regional Blood Donation Center, while blank urine and tissues (brain, kidney, liver and stomach wall) were collected during autopsies performed in Department of Forensic Medicine. Blank samples were screened prior to spiking to ensure that they were free from drugs. Forensic biological fluids (blood, urine, bile, vitreous humor, gastric content) and tissues (brain, liver, kidney, stomach wall) were sent to our laboratory, for toxicological analyses.

\section{Working solutions, calibration curve, and quality control samples}

The stock and standard solutions were stored at $-20{ }^{\circ} \mathrm{C}$. Standard solutions were diluted with methanol to obtain working standard solutions at the following concentrations for 4-FiBF: 1, 2, 5, 10, 20, 50, 100, 200 and $500 \mathrm{ng} /$ $\mathrm{mL}$. Calibration points and quality control (QC) samples were prepared by mixing the appropriate 4-FiBF working solution with blank whole blood, urine, and homogenates of brain, kidney, liver and stomach wall samples. The final concentrations of the calibrators were 0.1 (lower limit of quantification; LLOQ) , 0.2, 0.5, 1, 2, 5, 10, 20 and 50 (upper limit of quantification; ULOQ) $\mathrm{ng} / \mathrm{mL}$ (biological fluids) or $\mathrm{ng} / \mathrm{g}$ (solid tissues) for 4-FiBF. Quality control samples were prepared by spiking blank human whole blood, urine, and homogenates of brain, kidney, liver and stomach wall to yield final concentration of 0.2 (low QC), 2.0 (medium QC) and 20 (high QC) ng/mL or ng/g.

\section{Sample preparation}

A $0.5-\mathrm{mL}$ volume of biological fluid (blood, urine, bile, vitreous humor, gastric content) or $500 \mathrm{mg}$ of homogenized tissue sample (brain, liver, kidney, stomach wall) was transferred into $10-\mathrm{mL}$ plastic vials. Next, $20 \mu \mathrm{L}$ of methanolic IS solution (fentanyl- $d_{5}, 100 \mathrm{ng} / \mathrm{mL}$ ) and 0.5 $\mathrm{mL}$ of $0.5 \mathrm{M}$ ammonium carbonate buffer $(\mathrm{pH} 9)$ were added. Liquid-liquid extraction (LLE) with $2 \mathrm{~mL}$ of ethyl acetate was carried out for $10 \mathrm{~min}$. The samples were centrifuged for $10 \mathrm{~min}\left(2540 \times g\right.$ at $\left.4{ }^{\circ} \mathrm{C}\right)$. The organic phase was transferred into 2-mL Eppendorf tubes and evaporated to dryness under a stream of inert nitrogen gas at $40{ }^{\circ} \mathrm{C}$. The dry residues were dissolved in $50 \mu \mathrm{L}$ of methanol. The solution was then transferred into glass inserts of autosampler vials and analyzed by UHPLC-QqQ-MS/MS . Because the concentrations of 4-FiBF in most biological 
fluids and tissues were markedly above ULOQ (50 ng/mL), the assay was repeated. Blood, urine, vitreous humor and brain samples were diluted with water (LC-MS grade) tenfold, while bile, kidney, liver, stomach wall and gastric content samples were diluted with water tenfold twice, finally obtaining a 100-fold dilution. To homogenize the tissue samples, $1 \mathrm{~g}$ of solid specimen (brain, kidney, liver, stomach wall) was transferred to plastic tube $(12 \mathrm{~mL})$ and mixed with $1 \mathrm{~mL}$ of water (LC-MS grade). The tube was placed in a glass beaker containing ice cubes. The contents of the tube was homogenized using a Q55 sonicator (QSonica, Newtown, USA).

\section{Chromatographic and spectrometric conditions}

Analyses were performed using an UHPLC, Shimadzu Nexera X2 (Kyoto, Japan). The separation was done using a Kinetex XB-C18 column $(150 \times 2.1 \mathrm{~mm}$ i.d., particle size $2.6 \mu \mathrm{m}$; Phenomenex, Torrance, CA, USA) with the thermostat set at $40{ }^{\circ} \mathrm{C}$. The mobile phase consisted $0.1 \%$ formic acid in water (A) and $0.1 \%$ formic acid in acetonitrile (B). The gradient elution was carried out at a constant flow of $0.4 \mathrm{~mL} / \mathrm{min}$. The gradient applied was as follows: $0 \mathrm{~min}, 5 \% \mathrm{~B} ; 12 \mathrm{~min}, 98 \% \mathrm{~B} ; 14 \mathrm{~min}, 98 \% \mathrm{~B}$; and $15 \mathrm{~min}$, $5 \%$ B. Return to the initial gradient compositions $(95 \%$ $\mathrm{A} / 5 \% \mathrm{~B}$ ) was performed for $5 \mathrm{~min}$. The injection volume was $2.0 \mu \mathrm{L}$.

Detection of the investigated compounds was achieved using a QqQ-MS/MS, Shimadzu 8050 (Kyoto, Japan). The spectrometer was equipped with an electrospray ionization (ESI) source; determination of the investigated substances was carried out in the multiple reaction monitoring (MRM) mode. The following MS parameters were fixed: nebulizing gas flow, $3 \mathrm{~L} / \mathrm{min}$; heating gas flow, $10 \mathrm{~L} / \mathrm{min}$; interface temperature, $250{ }^{\circ} \mathrm{C}$; desolvation line temperature, $200{ }^{\circ} \mathrm{C}$; heat block temperature, $350{ }^{\circ} \mathrm{C}$; and drying gas flow, $10 \mathrm{~L} / \mathrm{min}$. A summary of precursor and product ions, collision energies, dwell time, Q1-Q3 pre-bias voltages, and retention time for each compound is presented in Table 1.

\section{Validation}

Validation of the method included examination of selectivity, linearity, precision and accuracy, carryover, limit of detection and quantification, recovery and matrix effect.

\section{Selectivity}

Ten different lots of blank whole blood, and five different lots of urine, brain, kidney, liver, stomach wall samples from different origin were tested for possible endogenous interference peaks at the retention times of 4-FiBF and IS.

\section{Linearity}

Linearity was evaluated by analysis of 4-FiBF working solutions with blank whole blood, urine, brain, kidney, liver and stomach wall in final concentrations of $0.1,0.2,0.5,1,2,5$, 10, 20 and $50 \mathrm{ng} / \mathrm{mL}$ or $\mathrm{ng} / \mathrm{g}$. Linear calibration model was applied. The coefficient of determination $\left(R^{2}\right)$ were determined. According to the acceptance criteria used, the coefficient of determination should meet the condition: $R^{2} \geq 0.995$.

\section{Precision and accuracy}

The intra-day and inter-day precision and accuracy were estimated by replicating analysis $(n=5)$ of QC samples at three concentration levels: 0.2, 2.0 and $20 \mathrm{ng} / \mathrm{mL}$ or ng/g. Precision was defined as relative standard deviation (RSD\%), while accuracy was expressed as mean relative error (RE\%).

\section{Carryover}

To investigate the carryover, three samples of each matrix type without analytes were analysed after a calibration sample at the 4-FiBF concentration in highest calibration level

Table 1 Multiple reaction monitoring (MRM) conditions used in the high-performance liquid chromatography-electrospray ionization-tandem mass spectrometry (HPLC-ESI-MS/MS) method for quantification of 4-fluoroisobutyryl fentanyl (4-FiBF) in biological samples

\begin{tabular}{llllllll}
\hline Compound & $\begin{array}{l}\text { Precursor ion } \\
(\mathrm{m} / \mathrm{z})\end{array}$ & Product ion $(\mathrm{m} / z)$ & $\begin{array}{l}\text { Dwell time } \\
(\mathrm{msec})\end{array}$ & Q1 pre-bias $(\mathrm{V})$ & $\begin{array}{l}\text { Collision } \\
\text { energy }(\mathrm{V})\end{array}$ & $\begin{array}{l}\text { Q3 pre-bias (V) } \\
\text { Retention } \\
\text { time (min) }\end{array}$ \\
\hline Fentanyl- $d_{5}$ & 342.1 & 188.3 & 7.0 & 10.0 & 25.0 & 19.0 & 5.68 \\
& & $105.2^{*}$ & 2.0 & 10.0 & 39.0 & 16.0 & 18.0 \\
4-FiBF & 369.4 & $188.2^{*}$ & & 16.0 & 25.0 & 16.0 & 6.31 \\
& & 105.2 & & 10.0 & 34.0 & 14.0 & \\
\hline
\end{tabular}

*Ions selected for quantitative analysis 
of $50 \mathrm{ng} / \mathrm{mL}$ or $50 \mathrm{ng} / \mathrm{g}$. Unacceptable carry over was when peak area ratio in a zero sample exceeded $20 \%$ of the area ratio observed for the LLOQ samples.

\section{The LLOQ and the LOD}

The LLOQ was defined as the concentration at which the RSD $\%$ and RE\% do not exceed $20 \%$ and $15 \%$, respectively [19]. The limit of detection (LOD) was considered to be the lowest concentration of the sample for which the signal-tonoise ratio met the condition at least: $\mathrm{S} / \mathrm{N} \geq 3$.

\section{Recovery and matrix effect}

The recovery and matrix effect were evaluated at each of the three different concentrations: $0.2,2.0$ and $20 \mathrm{ng} / \mathrm{mL}$ or $\mathrm{ng} / \mathrm{g}$. The recovery $(\%, n=5)$ was determined by comparing the response of extracted analyte in spiked blank matrix with the response of analyte spiked after the extraction of blank matrix. The matrix effect (\%bias, $n=5$ ) was determined by comparing the response of analyte spiked after the extraction of blank matrix with the response of analyte in neat solution [20].

\section{Results}

\section{Validation process}

Under the chromatographic conditions, the $\mathrm{m} / \mathrm{z}$ transitions of $369.4 \rightarrow 188.2,369.4 \rightarrow 105.2,369.4 \rightarrow 150.1$ and $342.1 \rightarrow 188.3$, 342.1 $\rightarrow 105.2$ were selected for optimal monitoring of $4-\mathrm{FiBF}$ and fentanyl- $d_{5}$, respectively. No interfering ion current signals were observed at the retention times of 4-FiBF or IS. Chromatograms of the blank blood sample, 4-FiBF at concentration of LOQ and real analysis of the blood sample in case 1 (diluted tenfold) are presented in Fig. 1. Product ion spectra of 4-FiBF and fentanyl- $d_{5}$ (IS) in the tested blood sample are presented in Fig. 2. Chromatograms of blank samples and 4-FiBF at concentration of LOQ in five types of matrix: urine, brain, kidney, stomach wall and liver are presented in Fig. 3. The linear concentration range was from 0.1 to $50 \mathrm{ng} / \mathrm{mL}$ (for biological fluids) and 0.1 to $50 \mathrm{ng} / \mathrm{g}$ (for solid tissues). Analysis of higher concentrations of 4-FiBF in the samples cause the saturation of the detector, thus, ULOQ was determined as a concentration of $50 \mathrm{ng} / \mathrm{mL}$ or $50 \mathrm{ng} / \mathrm{g}$. A summary of calibration curve parameters for each biological matrix is presented in Table 2. The LLOQ was $0.1 \mathrm{ng} / \mathrm{mL}$ (for biological fluids) and $0.1 \mathrm{ng} / \mathrm{g}$ (for solid tissues). The analysis of the sample spiked with a lower concentration $(0.05 \mathrm{ng} / \mathrm{mL}$ and 0.05 $\mathrm{ng} / \mathrm{g}$ ) showed that the signal from analyte was also visible but the RSD exceeded 20\%. Because lower concentration samples were not analyzed, $0.05 \mathrm{ng} / \mathrm{mL}$ and $0.05 \mathrm{ng} / \mathrm{g}$ was determined as the LOD of the method. Intra-day and interday precisions (RSD\%) and accuracies (RE\%) examined at 4-FiBF concentrations of low, medium and high QC, did not exceed $20 \%$. Recovery and matrix effect values were in the range $86.9-110 \%$ and $-13.1-10.4 \%$, respectively. Furthermore, there were no substances carried over between samples. A summary of the validation parameters is presented in Table 2.

\section{Toxicological analysis of biological samples}

Distribution of 4-FiBF in postmortem biological fluids (blood, urine, bile, vitreous humor, gastric content) and tissues (brain, liver, kidney, stomach wall) in four fatal intoxication cases is presented in Table 3. Determination of 4-FiBF in vitreous humor, bile, and gastric content was performed on urine, blood, and gastric homogenate calibration curves, respectively. The average concentration of 4-FiBF in the tested specimens was as follows: $140 \mathrm{ng} / \mathrm{mL}$ in the blood (range $76.1-257 \mathrm{ng} / \mathrm{mL}$ ), $642 \mathrm{ng} / \mathrm{mL}$ in the urine (range $289-1000 \mathrm{ng} / \mathrm{mL}$ ), $117 \mathrm{ng} / \mathrm{mL}$ in the vitreous humor (range $89.9-150 \mathrm{ng} / \mathrm{mL}$ ), $3390 \mathrm{ng} / \mathrm{mL}$ in the bile (range: $1100-5410$ $\mathrm{ng} / \mathrm{mL}$ ), $3310 \mathrm{ng} / \mathrm{mL}$ in the gastric content (range 2280-3990 $\mathrm{ng} / \mathrm{mL}$ ), $134 \mathrm{ng} / \mathrm{g}$ in the brain (range $94.5-176 \mathrm{ng} / \mathrm{g}$ ), 1650 $\mathrm{ng} / \mathrm{g}$ in the liver (range 1400-2040 ng/g) and $588 \mathrm{ng} / \mathrm{g}$ in the kidney (range $388-811 \mathrm{ng} / \mathrm{g}$ ). In case 3, the concentration of 4-FiBF in the stomach wall was $1900 \mathrm{ng} / \mathrm{g}$. Among all tested biological fluids, the highest concentrations of 4-FiBF were found in the bile and gastric content, while among tested tissues, in the liver. The lowest percentage of total body distribution of 4-FiBF was in the blood, vitreous humor and brain. Further toxicological analysis of collected blood and urine samples in the four intoxication cases showed the presence of other drugs and NPS such as amphetamine and $N$-ethylpentylone in cases 1, 2 and 3 and cis-tramadol with metabolites, $\alpha$-pyrrolidinoisohexanophenone $(\alpha-\mathrm{PiHP})$ and 4-chloromethcathinone (4-CMC) in case 4 . The quantification of these NPS was performed by the validated methods previously published $[21,22]$. Detailed toxicological findings with concentrations of these substances and distribution in biological samples are presented in Table 4. Examination of the seized white powder in a plastic bag (from case 4) revealed that it included a mix of 4-FiBF $(40.25 \mathrm{mg})$ with $\alpha$-PiHP (1.84 mg).

\section{Discussion}

The most widely used method for the determination of 4-FiBF in biological samples is LC-MS, which are characterized by high levels of selectivity, sensitivity and accuracy. These parameters are essential for reliable verification of 

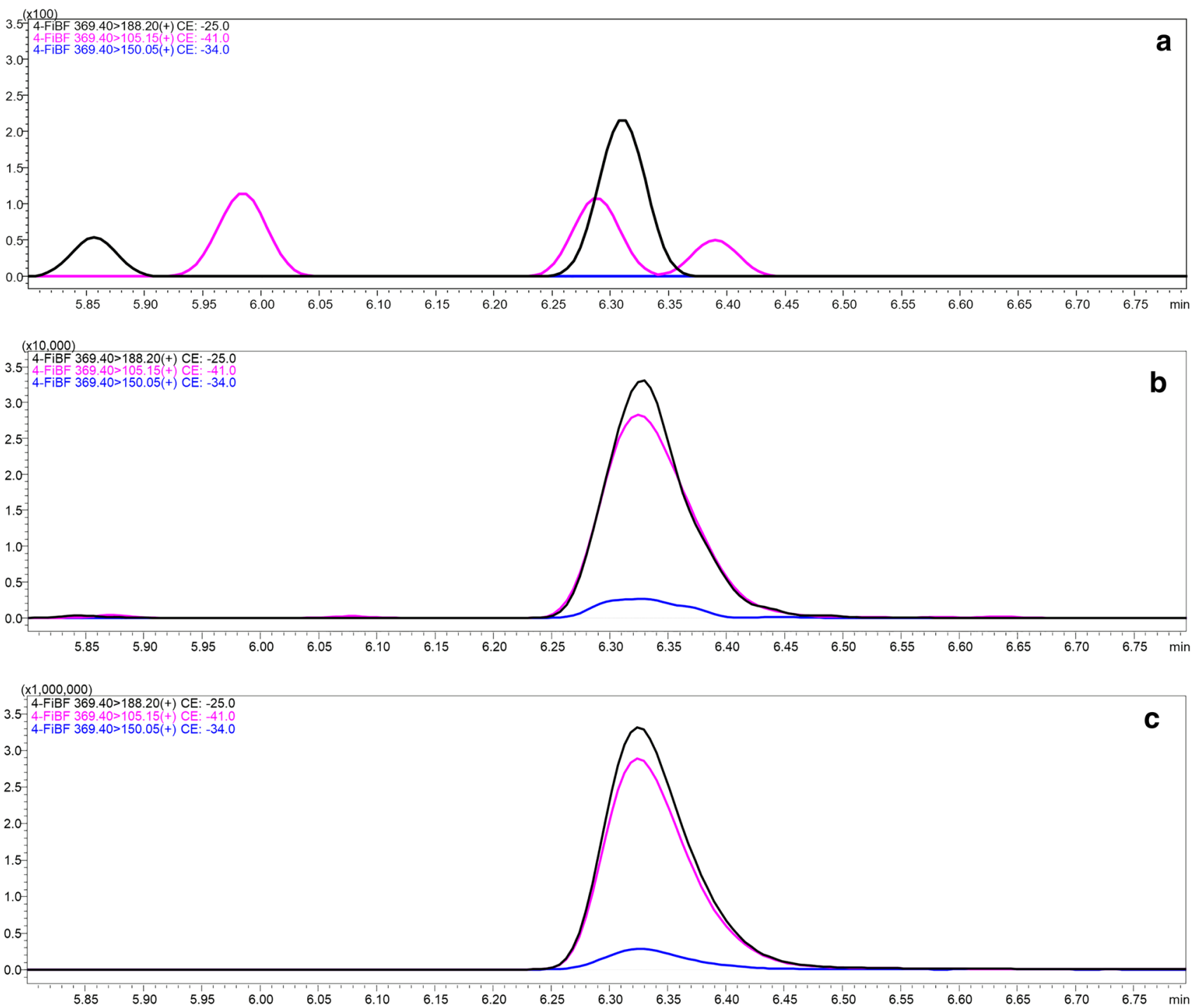

Fig. 1 Multiple reaction monitoring (MRM) chromatograms of a blank blood sample; b 4-fluoroisobutyryl fentanyl (4-FiBF) at the concentration of limit of quantification (LOQ): $0.1 \mathrm{ng} / \mathrm{mL}$; $\mathbf{c}$ real

fentanyl analog ingestions. A comparison of the methods applied for analysis of biological fluids in cases of 4-FiBF intoxication is presented in Table 5. Most of the articles described the methods with the use of triple quadrupole [11, 13, 14], however, ion trap [8] and triple quadrupole linear ion trap [15] systems have also been applied. Furthermore, the most widespread ion source was ESI, while detection of 4-FiBF was performed based on its fragmentation in the MRM mode [11, 13-15] or auto $\mathrm{MS}^{\mathrm{n}}$ [8]. All methods concerned on determination of 4-FiBF in whole blood samples analysis of blood sample in case 1 (diluted tenfold): 4-FiBF at concentration of $10.9 \mathrm{ng} / \mathrm{mL}$ (final concentration of $109 \mathrm{ng} / \mathrm{mL}$ in whole blood)

[11, 13-15], however, Shoff et al. [8] applied their method for analysis of both, whole blood and urine. All methods described to date have used fentanyl- $d_{5}$ as an IS. Due to its structural similarity to the determined 4-FiBF, it was possible to achieve very good recovery values ranging from $73.6 \%$ (in the work of Strayer et al.) [13] up to $99.7 \%$ (in the method described by Qin et al.) [15]. The lowest LOQ of the method $(0.05 \mathrm{ng} / \mathrm{mL})$ with the smallest sample volume $(100$ $\mu \mathrm{L}$ ) was achieved by Qin et al. [15]. However, the authors were the only ones who applied UHPLC-QTRAP-MS/MS, 

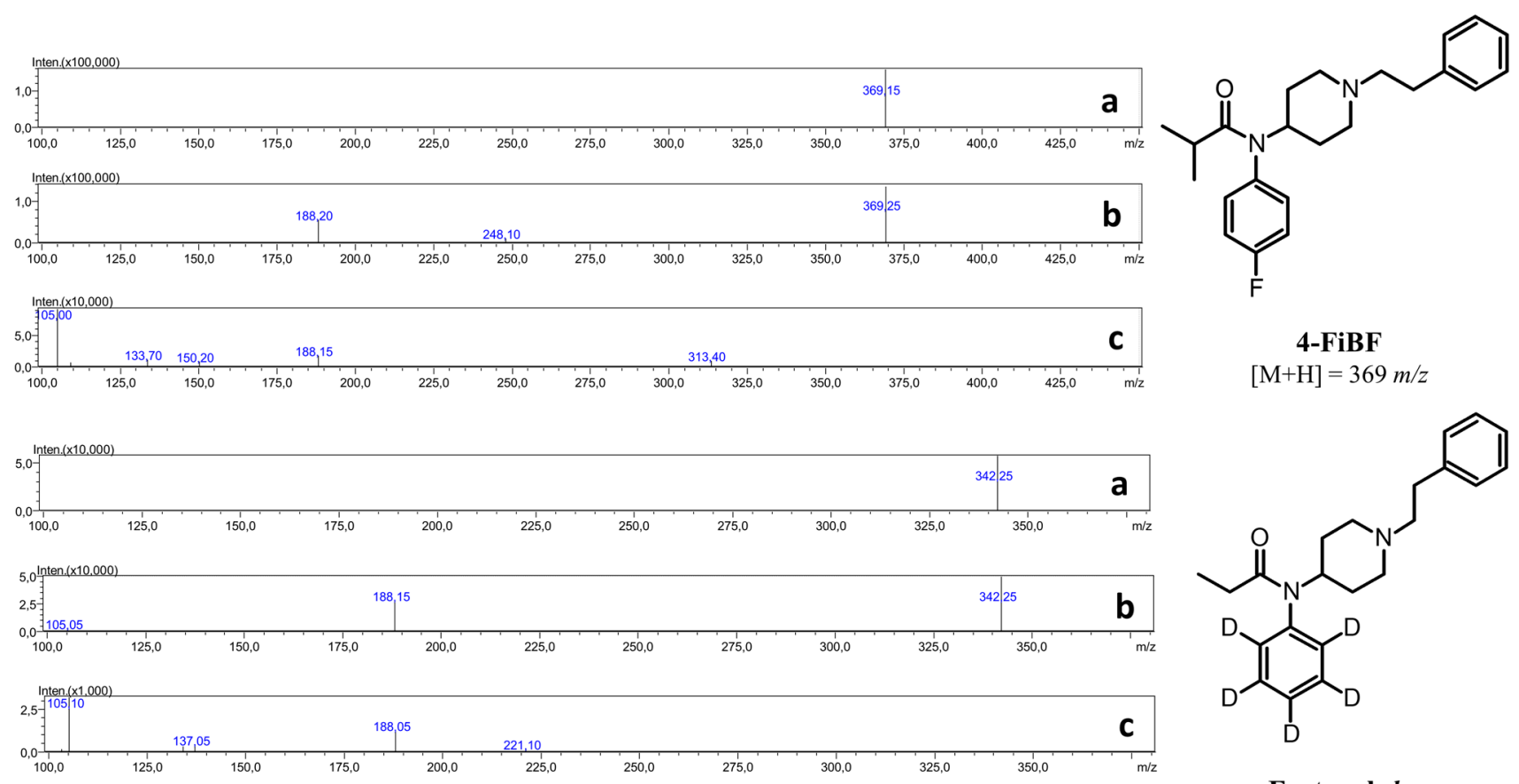

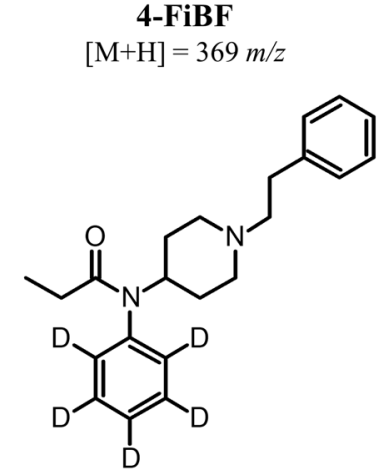

Fentanyl-ds

$[\mathrm{M}+\mathrm{H}]=342 \mathrm{~m} / \mathrm{z}$

Fig. 2 Product ion spectra of 4-FiBF and fentanyl- $d_{5}$ in authentic human blood; collision energy: a 10, b 20, and c $35 \mathrm{~V}$

which allows for much higher sensitivity through the availability of trapping ions before its further fragmentation. Shoff et al. [8] and Adamowicz et al. [14] determined only LOD of their methods, which were $0.5 \mathrm{ng} / \mathrm{mL}$ and $0.13 \mathrm{ng} /$ $\mathrm{mL}$, respectively. Nevertheless, it is difficult to compare both LOD and LOQ values reported by the authors due to the different injection volumes used. Most of the UHPLC-MS/ MS procedures described to date, as well as our method, achieved a LOQ at the concentration of $0.1 \mathrm{ng} / \mathrm{mL}$. However, the injection volumes ranged from $2.0 \mu \mathrm{L}$ (presented method) to $5.0 \mu \mathrm{L}[8,15]$ to as much as $10 \mu \mathrm{L}[11,14]$. Of the techniques described to date, more than half have been based on the use of solid-phase extraction (SPE) as a sample preparation procedure $[8,11,13]$. The most important highlights of this procedure is very good purification of the sample as well as obtaining a clear extract with concentrated analyte content. However, this preanalytical sample procedure is complicated and time consuming. Furthermore, the SPE techniques described by Shoff et al. [8] and Strayer et al. [13] required $1000 \mu \mathrm{L}$ of biological material. In this paper, as well as the two previous described methods $[14,15]$, an application of LLE technique in alkaline medium ( $\mathrm{pH}$ 9-11) with ethyl acetate as the organic phase was achieved. This technique of sample pre-treatment is fast and simple, while reducing of multi-stage preparation procedure allows to obtain better precision, accuracy and recovery values.

The results of toxicological analysis presented in this paper are the most detailed characterization of 4-FiBF concentrations in various biological samples. The reports on postmortem concentrations are limited to serum, blood and urine concentrations [7, 11]. Helander et al. [7] reported fatal ingestion of a $250-\mathrm{mg}$ dose of 4 -FiBF by a 27 -yearold male. Toxicological analysis of biological material collected $3.5 \mathrm{~h}$ after intoxication revealed 4-FiBF concentrations of $38 \mathrm{ng} / \mathrm{mL}$ and $31 \mathrm{ng} / \mathrm{mL}$ in the serum and urine, respectively. In turn, Pardi et al. [11] presented 247 cases in which the presence of 4-FiBF in blood samples was found. Concentrations of this synthetic fentanyl analog in postmortem blood samples ranged from 0.1 up to $331 \mathrm{ng} /$ $\mathrm{mL}$. The 4-FiBF concentrations described in this paper $(76.1-257 \mathrm{ng} / \mathrm{mL})$ are within those previously reported. The presented four fatal intoxications were associated with rapid (within minutes) loss of consciousness and death after the drug administration. Our results suggest that the 
Fig. 3 MRM chromatograms of blank samples and 4-FiBF at concentration of LOQ in five types of matrix: urine, brain, kidney, stomach wall and liver

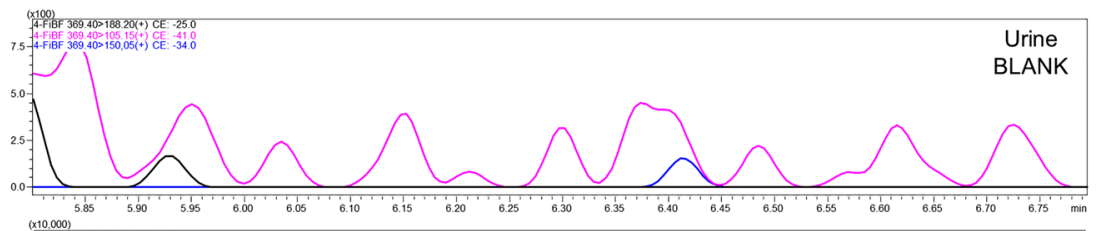

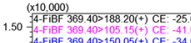
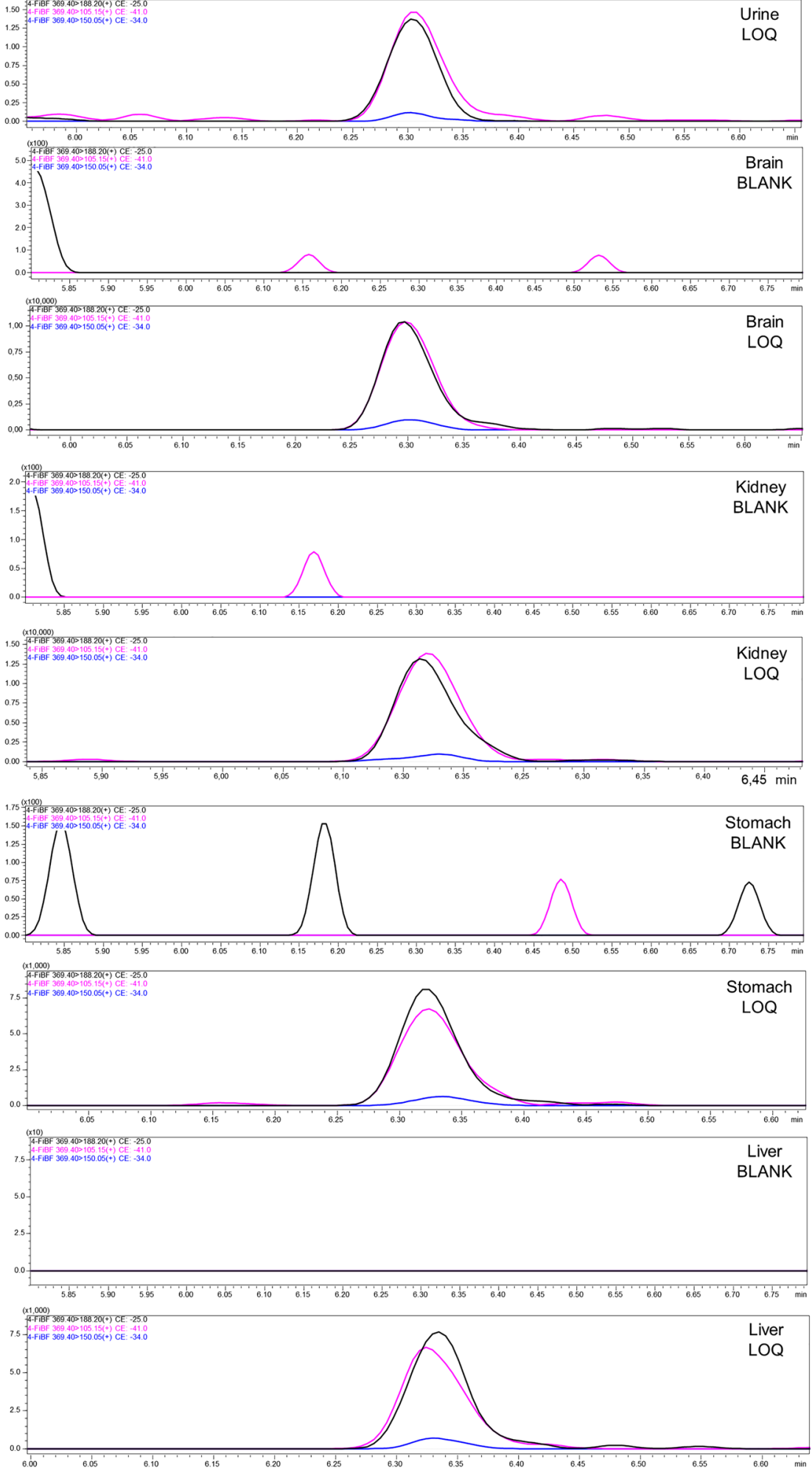


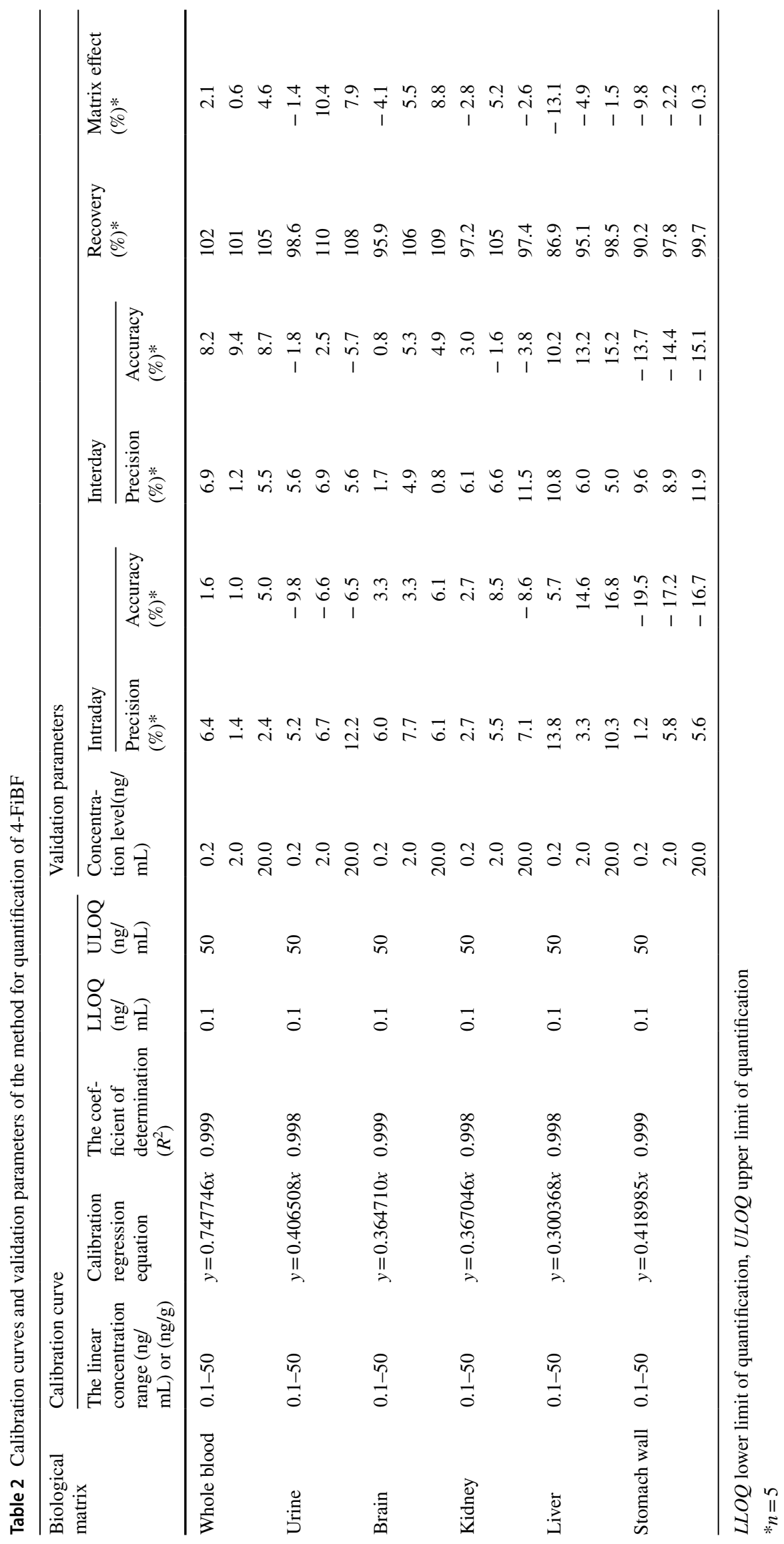


Table 3 Distribution of 4-FiBF in postmortem samples (biological fluids and tissues)

\begin{tabular}{|c|c|c|c|c|c|c|c|c|c|}
\hline Case number & $\begin{array}{l}\text { Blood (ng/ } \\
\mathrm{mL})\end{array}$ & $\begin{array}{l}\text { Urine (ng/ } \\
\mathrm{mL} \text { ) }\end{array}$ & $\begin{array}{l}\text { Vitreous } \\
\text { humor (ng/ } \\
\mathrm{mL} \text { ) }\end{array}$ & Bile (ng/mL) & Brain (ng/g) & Kidney (ng/g) & Liver (ng/g) & $\begin{array}{l}\text { Stomach } \\
\text { wall } \\
(\mathrm{ng} / \mathrm{g})\end{array}$ & $\begin{array}{l}\text { Gastric } \\
\text { content (ng/ } \\
\mathrm{mL})\end{array}$ \\
\hline Case 1 & 109 & 635 & 150 & 5410 & 176 & 811 & 1400 & $-^{\mathrm{a}}$ & 3670 \\
\hline Case 2 & 76.1 & 1000 & 89.9 & 1100 & 94.5 & 388 & 1620 & - & 3990 \\
\hline Case 3 & 257 & - & 128 & 3670 & 154 & 564 & 2040 & 1900 & - \\
\hline Case 4 & 119 & 289 & 101 & - & 112 & - & 1540 & - & 2280 \\
\hline
\end{tabular}

${ }^{a}$ Not determined

distribution of 4-FiBF is very rapid, and concentrations of the xenobiotic in the liver, bile, and kidney are many orders of magnitude higher than in blood concentrations. However, in the case of co-administered cathinone analogs (4-CMC and $N$-ethylpentylone), the differences were not as significant. Nevertheless, taking into account the coincidence of 4-FiBF with cathinones (which are unstable in blood samples [21, 23-25]), and the high concentrations of 4-FiBF in the liver, it is appropriate to collect the fragment of this tissue together with blood samples for further toxicological studies. The elimination of 4-FiBF occurs rapidly, and the urinary concentrations are extremely high. It appears to be inversely proportional to the blood concentration-in our cases, as the blood concentration of 4-FiBF decreased, an increase in the urinary concentration was observed, which may suggest that this is the main pathway of elimination of this compound from the body. An interesting finding was observed in the case of quantification of 4-FiBF in the gastric contents and stomach wall, as particularly high concentrations of this substance were found there. The results are even more surprising, as all four decedents ingested 4-FiBF by inhalation before their deaths (this fact was described in detail by the witnesses). Therefore, it seems that the presence of 4-FiBF in the gastrointestinal tract was the result of saliva or smoke swallowing while smoking.

The examination of the seized white powder (from case 4) revealed the presence of a mix of two NPS belonging to the group of synthetic cathinones ( $\alpha$-PiHP) and fentanyls (4-FiBF). To our knowledge, such an unusual combination of these two drugs has not been reported to date. The local nature of this trend seems to be confirmed by the fact that in 2020 Adamowicz et al. [14] reported a fatal intoxication case which occurred in Poland. The determined concentrations of 4-FiBF along with $\alpha$-PiHP in the postmortem blood sample were $74 \mathrm{ng} / \mathrm{mL}$ and $56 \mathrm{ng} / \mathrm{mL}$, respectively. In our cases, the intoxication with a mixture of $4-\mathrm{FiBF}$ and $\alpha$-PiHP, and in addition with 4-CMC and tramadol was found. However, the blood concentrations of 4-FiBF and $\alpha$-PiHP described in this paper's UHPLC-QqQ-MS/MS analysis $(119 \mathrm{ng} / \mathrm{mL}$ and $6.1 \mathrm{ng} / \mathrm{mL}$, respectively) differed from those obtained by Adamowicz et al. [14]. These differences were most likely due to the different proportions of psychoactive substances in the drugs used.

\section{Conclusions}

An UHPLC-QqQ-MS/MS method for 4-FiBF determination has been evaluated and fully validated. The method described in this paper was applied in 4-FiBF determination in four fatal intoxications. The distribution study of 4 -FiBF as well as other NPS ( $N$-ethylpentylone, $\alpha$-PiHP and 4-CMC) was performed on a wide range of postmortem biological fluids (blood, urine, vitreous humor, bile, gastric content) and tissues (brain, kidney, liver, stomach wall). Examinations of the seized drug (in case 4) revealed that it included a mix of 4-FiBF and $\alpha-\mathrm{PiHP}$, which is the first report to our knowledge of such an unusual combination of these two drugs on the global drug market. 


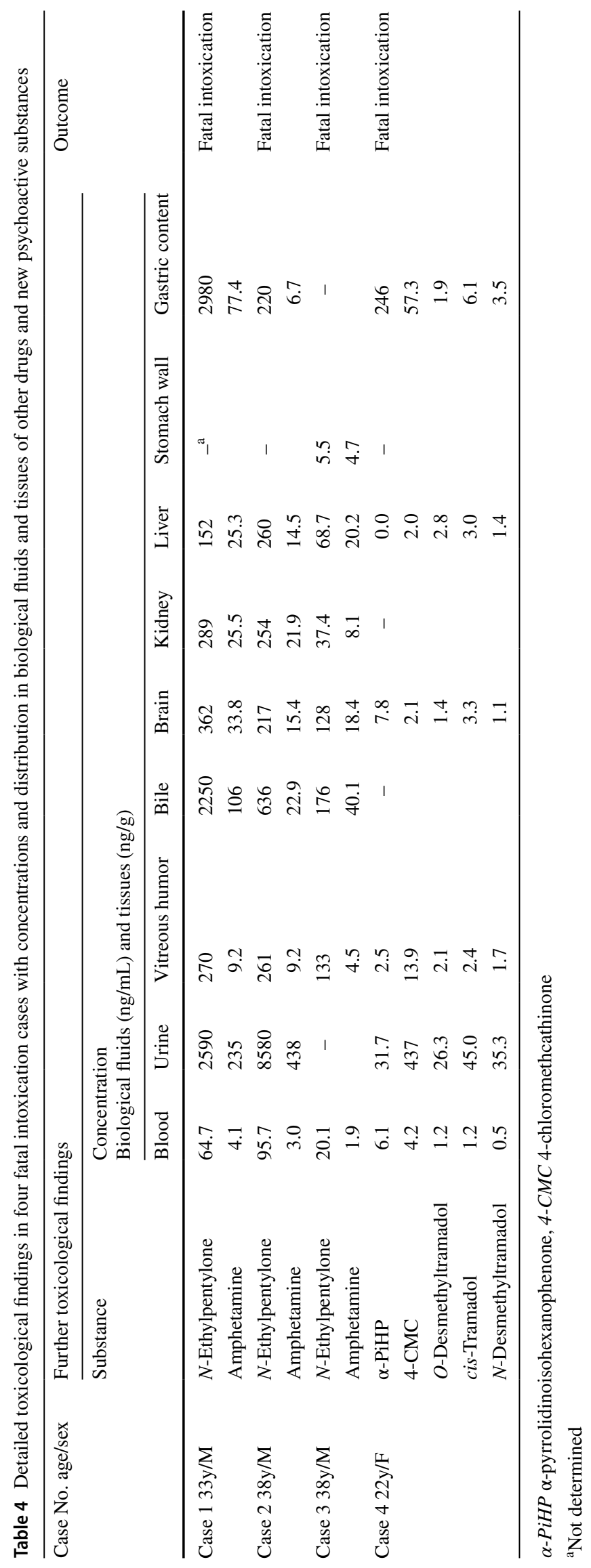


Table 5 Comparison of determinations of 4-FiBF in biological samples by liquid chromatography coupled with mass spectrometry methods

\begin{tabular}{|c|c|c|c|c|c|c|c|c|c|}
\hline $\begin{array}{l}\text { Biological } \\
\text { sample (vol- } \\
\text { ume) }\end{array}$ & $\begin{array}{l}\text { Sample prepa- } \\
\text { ration }\end{array}$ & $\begin{array}{l}\text { Detector } \\
\text { (mode) }\end{array}$ & $\begin{array}{l}\text { Injection } \\
\text { volume } \\
(\mu \mathrm{L})\end{array}$ & $\begin{array}{l}\text { Recovery } \\
(\%) / \text { internal } \\
\text { standard }\end{array}$ & $\begin{array}{l}\text { Precision/ } \\
\text { accuracy (\%) }\end{array}$ & $\begin{array}{l}\mathrm{LOQ}(\mathrm{ng} / \\
\mathrm{mL}) \text { or } \\
(\mathrm{ng} / \mathrm{g})\end{array}$ & $\begin{array}{l}\text { Concentra- } \\
\text { tions in } \\
\text { biological } \\
\text { samples (ng/ } \\
\mathrm{mL}) \text { or (ng/g) }\end{array}$ & Year & References \\
\hline $\begin{array}{l}\text { Whole blood } \\
\text { Urine }(1000 \\
\mu L)\end{array}$ & $\begin{array}{l}\text { SPE (Clean } \\
\text { Screen Dau) }\end{array}$ & $\begin{array}{l}\text { ESI/Ion trap } \\
\quad\left(\text { auto } \mathrm{MS}^{\mathrm{n}}\right)\end{array}$ & 5.0 & $\begin{array}{l}-{ }^{\mathrm{a}} \\
\text { Fentanyl- } d_{5}\end{array}$ & $-^{\mathrm{a}}$ & $-{ }^{\mathrm{a}}$ & $-^{\mathrm{a}}$ & 2017 & [8] \\
\hline $\begin{array}{l}\text { Whole blood } \\
\qquad(1000 \mu \mathrm{L})\end{array}$ & $\begin{array}{l}\text { SPE (Clean } \\
\text { Screen Dau) }\end{array}$ & $\begin{array}{l}\text { ESI/triple } \\
\text { quadrupole } \\
\text { (MRM) }\end{array}$ & - & $\begin{array}{l}73.6-87.9 \\
\text { Fentanyl- } d_{5}\end{array}$ & $\begin{array}{l}88.0-92.1^{\mathrm{b}} \\
4.7-19.0^{\mathrm{c}}\end{array}$ & 0.1 & - & 2018 & [13] \\
\hline $\begin{array}{l}\text { Whole blood } \\
\qquad(100 \mu \mathrm{L})\end{array}$ & $\begin{array}{l}\text { LLE (pH 9.2) } \\
\text { with ethyl } \\
\text { acetate }\end{array}$ & $\begin{array}{l}\text { ESI/QTRAP } \\
\text { (MRM) }\end{array}$ & 5.0 & $\begin{array}{l}88.1-99.7 \\
\text { Fentanyl- } d_{5}\end{array}$ & $\begin{array}{l}3.6-11.3^{b} \\
86.6-100.5^{c}\end{array}$ & 0.05 & - & 2019 & [15] \\
\hline $\begin{array}{l}\text { Whole blood } \\
(200 \mu \mathrm{L})\end{array}$ & $\begin{array}{l}\text { LLE (pH 11) } \\
\text { with ethyl } \\
\text { acetate }\end{array}$ & $\begin{array}{l}\text {-/triple } \\
\text { quadrupole } \\
\text { (MRM) }\end{array}$ & 10.0 & $\begin{array}{l}82.2 \\
\text { Fentanyl- } d_{5}\end{array}$ & $\begin{array}{l}3.2-4.6^{\mathrm{d}} \\
6.8-13.2^{\mathrm{c}}\end{array}$ & - & 74.0 & 2019 & [14] \\
\hline $\begin{array}{l}\text { Whole blood } \\
\qquad(500 \mu \mathrm{L})\end{array}$ & $\begin{array}{l}\text { SPE (Clean } \\
\text { Screen Xcel } \\
\text { I) }\end{array}$ & $\begin{array}{l}\text { ESI/triple } \\
\text { quadrupole } \\
\text { (MRM) }\end{array}$ & 10.0 & $\begin{array}{l}-^{\mathrm{a}} \\
\text { Fentanyl- } d_{5}\end{array}$ & $\begin{array}{l}1.8-12.0^{b} \\
4.3-7.3^{c}\end{array}$ & 0.1 & $0.1-331.0$ & 2020 & [11] \\
\hline $\begin{array}{l}\text { Whole blood } \\
\text { Urine } \\
\text { Vitreous } \\
\text { humor }\end{array}$ & $\begin{array}{l}\text { LLE (pH 9) } \\
\text { with ethyl } \\
\text { acetate }\end{array}$ & $\begin{array}{l}\text { ESI/triple } \\
\text { quadrupole } \\
\text { (MRM) }\end{array}$ & 2.0 & $\begin{array}{l}101-105 \\
\quad \text { (blood) } \\
\text { Fentanyl- } d_{5}\end{array}$ & $\begin{array}{l}1.2-6.9^{\mathrm{d}} \\
1.0-9.4^{\mathrm{c}} \\
\text { (blood) }\end{array}$ & 0.1 & $\begin{array}{l}76.1-257 \\
289-1000 \\
89.9-150\end{array}$ & 2021 & $\begin{array}{l}\text { Presented } \\
\text { study }\end{array}$ \\
\hline Bile & & & & & & & $1100-5410$ & & \\
\hline $\begin{array}{l}\text { Gastric content } \\
(500 \mu \mathrm{L})\end{array}$ & & & & & & & $2280-3990$ & & \\
\hline $\begin{array}{l}\text { Brain homoge- } \\
\text { nate }\end{array}$ & & & & & & & $94.5-176$ & & \\
\hline $\begin{array}{l}\text { Kidney } \\
\text { homogenate }\end{array}$ & & & & & & & $388-811$ & & \\
\hline $\begin{array}{l}\text { Liver homoge- } \\
\text { nate }\end{array}$ & & & & & & & $1400-2040$ & & \\
\hline $\begin{array}{l}\text { Stomach wall } \\
\text { homogenate } \\
(500 \mathrm{mg})\end{array}$ & & & & & & & 1900 & & \\
\hline
\end{tabular}

$L O Q$ limit of quantification, $S P E$ solid-phase extraction, $L L E$ liquid-liquid extraction, $Q T R A P$ triple quadrupole linear ion trap

${ }^{a}$ Information was not detailed in article

${ }^{\mathrm{b}}$ Coefficient of variation

${ }^{c}$ Relative error

${ }^{\mathrm{d}}$ Relative standard deviation

\section{Declarations}

Conflict of interest The authors declare no conflicts of interest (including financial and personal) that might appear to influence the work reported in this paper.

Ethical approval All procedures performed in this study were in accordance with the ethical standards of the national committee and with the 1964 Declaration of Helsinki. Biological fluids (blood, urine, bile, vitreous humor, gastric content) and tissues (brain, liver, kidney, stomach wall) collection from decedents was made by judicial authorities, and the samples were sent to our institute for toxicological analysis at their request. The blank biological materials used to develop the method were collected in accordance with Ethical Committee approval
(No. 333/14). This article does not contain any studies with living human participants or animals performed by any of the authors.

Open Access This article is licensed under a Creative Commons Attribution 4.0 International License, which permits use, sharing, adaptation, distribution and reproduction in any medium or format, as long as you give appropriate credit to the original author(s) and the source, provide a link to the Creative Commons licence, and indicate if changes were made. The images or other third party material in this article are included in the article's Creative Commons licence, unless indicated otherwise in a credit line to the material. If material is not included in the article's Creative Commons licence and your intended use is not permitted by statutory regulation or exceeds the permitted use, you will 
need to obtain permission directly from the copyright holder. To view a copy of this licence, visit http://creativecommons.org/licenses/by/4.0/.

\section{References}

1. European Monitoring Centre for Drugs and Drug Addiction (2020) European drug report 2020: trends and developments. https://www.emcdda.europa.eu/system/files/publications/-13236/ TDAT20001ENN_web.pdf. Accessed 17 Feb 2020

2. United Nations Office on Drugs and Crime (2020) Global SMART update: the growing complexity of the opioid crisis. https://www. unodc.org/documents/scientific/Global_-SMART-2020-Vol_24_ web.pdf. Accessed 17 Feb 2020

3. United Nations Office on Drugs and Crime (2020) Synthetic drugs in East and Southeast Asia: latest developments and challenges. https://www.unodc.org/documents/scientific/-ATS/2020_ESEA_ Regonal_Synthetic_Drug_Report_web.pdf. Accessed 17 Feb 2020

4. Slovenian National Forensic Laboratory (2016) Analytical report $4 \mathrm{~F}-\mathrm{iBF}$. European project RESPONSE to challenges in forensic drugs analyses. https://www.policija.si/apps/nfl-_response_ web/0_Analytical_Reports_final/4F-iBF-ID-1573-16_rpt100816. pdf. Accessed 17 Feb 2020

5. European Monitoring Centre for Drugs and Drug AddictionEuropol (2017) 4F-iBF. EMCDDA-Europol Joint Report on a new psychoactive substance: $N$-(4-fluorophenyl)- $N$-(1-phenethylpiperidin-4-yl)isobutyramide (4-fluoroisobutyrylfentanyl; 4F-iBF). https://www.emcdda.europa.eu/system/files/publicatio ns/5482/2017.4967_TDAS17007ENN_PDFWEB.pdf. Accessed 17 Feb 2020

6. European Monitoring Centre for Drugs and Drug Addiction (2017) Technical report on $N$-(4-fluorophenyl)- $N$-(1-phenethylpiperidin-4-yl)isobutyramide(4-fluoroisobutyrylfentanyl; 4F-iBF). http://researchonline.ljmu.ac.uk/id/eprint/7764/1/4F-iBF_RAR with\%20Annexes\%20and\%20cover.pdf. Accessed 17 Feb 2020

7. Helander A, Bäckberg M, Signell P, Beck O (2017) Intoxications involving acrylfentanyl and other novel designer fentanyls-results from the Swedish STRIDA project. Clin Toxicol 55:589-599. https://doi.org/10.1080/15563650.2017.1303141

8. Shoff EN, Zaney ME, Kahl JH, Hime GW, Boland DM (2017) Qualitative identification of fentanyl analogs and other opioids in postmortem cases by UHPLC-Ion Trap-MS ${ }^{\mathrm{n}}$. J Anal Toxicol 41:484-492. https://doi.org/10.1093/jat/bkx041(openaccessartic le)

9. Lamy FR, Daniulaityte R, Barratt MJ, Lokala U, Sheth A, Carlson RG (2020) Listed for sale: analyzing data on fentanyl, fentanyl analogs and other novel synthetic opioids on one cryptomarket. Drug Alcohol Depend. https://doi.org/10.1016/j.druga lcdep.2020.108115

10. Cheng WC, Dao KL (2020) Prevalence of drugs of abuse found in forensic testing of illicit drug seizures and urine samples from offenders/probationers in Hong Kong: a 3-year update. Forensic Sci Int. https://doi.org/10.1016/j.forsciint.2020.110535

11. Pardi J, Toriello A, Cooper G (2020) Evaluation of 4-fluoroisobutyrylfentanyl in blood samples from 247 authentic cases submitted to the New York City office of chief medical examiner in 2017-2018. Forensic Toxicol 38:340-351. https:// doi.org/10.1007/s11419-019-00518-6(openaccessarticle)
12. Wharton RE, Casbohm J, Hoffmaster R, Brewer BN, Finn MG, Johnson RC (2021) Detection of 30 fentanyl analogs by commercial immunoassay kits. J Anal Toxicol 45:111-116. https:// doi.org/10.1093/jat/bkaa181(openaccessarticle)

13. Strayer KE, Antonides HM, Juhascik MP, Daniulaityte R, Sizemore IE (2018) LC-MS/MS-based method for the multiplex detection of 24 fentanyl analogues and metabolites in whole blood at sub $\mathrm{ng} \mathrm{mL} \mathrm{mL}^{-1}$ concentrations. ACS Omega 3:514-523. https:// doi.org/10.1021/acsomega.7b01536

14. Adamowicz P, Bakhmut Z, Mikolajczyk A (2020) Screening procedure for 38 fentanyl analogues and five other new opioids in whole blood by liquid chromatography-tandem mass spectrometry. J Appl Toxicol 40:1033-1046. https://doi.org/10.1002/jat. 3962

15. Qin N, Xiang P, Shen B, Zhuo X, Shi Y, Song F (2019) Application of a validated UHPLC-MS/MS method for 28 fentanylanalogue and novel synthetic opioids in whole blood in authentic forensic cases. J Chromatogr B 1124:82-99. https://doi.org/10. 1016/j.jchromb.2019.05.025

16. Qin N, Shen M, Xiang P, Wen D, Shen B, Deng H, Qiang H, Song F, Shi Y (2020) Determination of 37 fentanyl analogues and novel synthetic opioids in hair by UHPLC-MS/MS and its application to authentic cases. Sci Rep 10:11569. https://doi.org/10.1038/ s41598-020-68348-w(openaccessarticle)

17. Buchalter S, Marginean I, Yohannan J, Lurie IS (2019) Gas chromatography with tandem cold electron ionization mass spectrometric detection and vacuum ultraviolet detection for the comprehensive analysis of fentanyl analogues. J Chromatogr A 1596:183-193. https://doi.org/10.1016/j.chroma.2019.03.011

18. Winokur AD, Kaufman LM, Almirall JR (2020) Differentiation and identification of fentanyl analogues using GC-IRD. Forensic Chem. https://doi.org/10.1016/j.forc.2020.100255

19. Peters FT, Drummer OH, Musshoff F (2007) Validation of new methods. Forensic Sci Int 165:216-224. https://doi.org/10.1016/j. forsciint.2006.05.021

20. Chambers E, Wagrowski-Diehl DM, Lu Z, Mazzeo JR (2007) Systematic and comprehensive strategy for reducing matrix effects in LC/MS/MS analyses. J Chromatogr B 852:22-34. https://doi. org/10.1016/j.jchromb.2006.12.030

21. Nowak K, Szpot P, Zawadzki M (2020) The stability of 4-chloromethcathinone in blood and vitreous humor. J Forensic Sci 65:1784-1790. https://doi.org/10.1111/1556-4029.14454

22. Zawadzki M, Nowak K, Szpot P (2020) Fatal intoxication with $\mathrm{N}$-ethylpentylone: a case report and method for determining $N$-ethylpentylone in biological material. Forensic Toxicol 38:255-263. https://doi.org/10.1007/s11419-019-00483-0(openaccessarticle)

23. Nowak K, Szpot P, Zawadzki M (2021) Fatal intoxication with U-47700 in combination with other NPS ( $N$-ethylhexedrone, adinazolam, 4-CIC, 4-CMC) confirmed by identification and quantification in autopsy specimens and evidences. Forensic Toxicol. https://doi.org/10.1007/s11419-020-00568-1

24. Adamowicz P, Malczyk A (2019) Stability of synthetic cathinones in blood and urine. Forensic Sci Int 295:36-45. https://doi.org/10. 1016/j.forsciint.2018.12.001

25. Nowak K, Szpot P, Zawadzki M (2019) Unstability of 4-CMC in human serum specimen. Forensic Toxicol 37:261-264. https://doi. org/10.1007/s11419-018-0455-4

Publisher's Note Springer Nature remains neutral with regard to jurisdictional claims in published maps and institutional affiliations. 